Article

\title{
Mitigation of Osmotic Stress in Cotton for the Improvement in Growth and Yield through Inoculation of Rhizobacteria and Phosphate Solubilizing Bacteria Coated Diammonium Phosphate
}

Muhammad Majid ${ }^{1}$, Muqarrab Ali ${ }^{1, *}$, Khurram Shahzad ${ }^{2}$ D, Fiaz Ahmad ${ }^{3}$ (D),

Rao Muhammad Ikram ${ }^{1}$, Muhammad Ishtiaq ${ }^{4}$, Ibrahim A. Alaraidh ${ }^{5}$,

Abdulrahman Al-hashimi ${ }^{5}$ (D), Hayssam M. Ali ${ }^{5}$, Tayebeh Zarei ${ }^{6}$, Rahul Datta ${ }^{7} *(\mathbb{D}$,

Shah Fahad 8,9,*, Ayman El Sabagh $10\left(\mathbb{D}\right.$, Ghulam Sabir Hussain 11, Mohamed Z. M. Salem ${ }^{12}$ (D),

Muhammad Habib-ur-Rahman 1,13 and Subhan Danish 14,*

1 Department of Agronomy, Muhammad Nawaz Sharif University of Agriculture, Multan 60800, Pakistan; majidmuhammad281@gmail.com (M.M.); rao.ikram@mnsuam.edu.pk (R.M.I.);

habib.rahman@mnsuam.edu.pk (M.H.-u.-R.)

2 Plant Nutrition Section, Mango Research Institute, Multan 60000, Pakistan;

khurram.balouch2576@gmail.com

3 Central Cotton Research Institute, Multan 60000, Pakistan; fiazdrccri@gmail.com

4 Department of Entomology, Muhammad Nawaz Sharif University of Agriculture, Multan 66000, Pakistan; m.ishtiaq@mnsuam.edu.pk

5 Department of Botany and Microbiology, College of Science, King Saud University, P.O. Box 2455,

Riyadh 11451, Saudi Arabia; ialaraidh@ksu.edu.sa (I.A.A.); aalhashimi@ksu.edu.sa (A.A.-h.);

hayhassan@ksu.edu.sa (H.M.A.)

6 Laboratory of Tropical and Mediterranean Symbioses, CIRAD, 34398 Montpellier, France; z.tayebe@yahoo.com

7 Department of Geology and Pedology, Faculty of Forestry and Wood Technology, Mendel University in Brno, Zemedelska1, 61300 Brno, Czech Republic

8 Hainan Key Laboratory for Sustainable Utilization of Tropical Bioresource, College of Tropical Crops, Hainan University, Haikou 570228, China

9 Department of Agronomy, The University of Haripur, Khyber Pakhtunkhwa 21120, Pakistan

10 Department of Agronomy, Faculty of Agriculture, Kafrelsheikh University, Kafr El-Shaikh 33516, Egypt; ayman.elsabagh@agr.kfs.edu.eg

11 Department of Agronomy, Faculty of Agricultural Sciences and Technology, Bahauddin Zakariya University, Multan 60800, Pakistan; hussainsabirsial90@yahoo.com

12 Forestry and Wood Technology Department, Faculty of Agriculture (El-Shatby), Alexandria University, Alexandria 21545,Egypt; zidan_forest@yahoo.com

13 Crop Science Group, Institute of Crop Science and Resource Conservation (INRES), University of Bonn, 53115 Bonn, Germany

14 Department of Soil Science, Faculty of Agricultural Sciences and Technology, Bahauddin Zakariya University, Multan 60800, Pakistan

* Correspondence: muqarrab.ali@mnsuam.edu.pk (M.A.); rahulmedcure@gmail.com (R.D.); shah_fahad80@yahoo.com (S.F.); sd96850@gmail.com (S.D.); Tel.: +92-304-799-6951 (S.D.)

Received: 23 October 2020; Accepted: 7 December 2020; Published: 14 December 2020

Abstract: Cotton (Gossypium hirsutum L.) is one of the major fiber crops. Its production is under threat due to scarcity of water resources under a changing climatic scenario. Limited water availability also decreases the uptake of phosphorus, and less uptake of phosphorus can deteriorate the quality attributes of cotton fiber. There is a need to introduce bio-organic amendments which can mitigate osmotic stress on a sustainable basis. Inoculation of rhizobacteria can play an imperative role 
in this regard. Rhizobacteria can not only improve the growth of roots but also enhance the availability of immobile phosphorus in soil. That is why the current experiment was conducted to explore and compare the efficacy of sole application of diammonium phosphate (DAP) over plant growth-promoting rhizobacteria (PGPR) and phosphorus solubilizing bacteria (PSB) coated DAP on growth and quality attributes of cotton under artificially induced osmotic stress at flowering stage. The impact of phosphorus levels was found to be significant on the plant height, leaf area, average boll weight, stomatal conductance, net photosynthetic rate, and seed cotton yield, while the irrigation effect was significant on all the parameters. The PGPR coated phosphorus performed better as compared to other treatments under normal irrigation and osmotic stress. Results showed that PGPR coated phosphorus increased by $29.47 \%, 21.01 \%, 41.11 \%, 32.73 \%, 15.63 \%$ and $22.89 \%$ plant height, average boll weight, stomatal conductance, net photosynthetic rate, fiber length, and seed cotton yield respectively. In conclusion, PGPR coated DAP can be helpful to get higher cotton productivity as compared to control and sole application of DAP under normal irrigation and osmotic stress.

Keywords: cotton; inorganic fertilizers; PGPR; PSB; osmotic stress

\section{Introduction}

Pakistan is the world's fifth largest producer of cotton after China, India, United States, Brazil and Pakistan second largest exporter and seventh largest producer of cloth in the world. The cotton production during 2018-2019 was 9.86 million bales from a cultivated area of 2.37 million ha. [1]. Cotton has $0.8 \%$ share in GDP and $4.5 \%$ contribution to agriculture. Cotton supports many industries such as terrycloth, used for making highly absorbent bath towels and robes, and denim, used for making blue jeans, chambray, and popularly used in making blue work shirts [2]. However, management of abiotic stresses is a major concern under a changing climatic situation [3-8].

The cotton production requires a sufficient amount of water during its vegetative and reproductive cycle. Water deficiency during cotton production affects leaf enlargement which causes reduction of energy. The cotton plant growth under water stress reduces stomatal conductance, leaf temperature, carbon dioxide assimilation rate, and chlorophyll contents [9]. Low soil moisture reduces root growth of the cotton. The flowering stage is affected more by water stress, which ultimately reduces boll formation and cotton yield [10]. In addition, water deficit conditions can create a negative response, disrupting hormonal stability in squares and bolls, which leads to fruit shedding [11]. Thus, water stress could be a major abiotic factor that could adversely affect plant growth, yield and fiber quality [12].

Water stress is an important factor which reduces the uptake of nutrients to the plants [13-16]. Moreover, limited water conditions suppress the availability of water in cotton. The availability of essential nutrients, especially phosphorus, under water deficit conditions could increase stomatal conductance, water-use efficiency, and net photosynthesis as well as increase cellular membrane stability, and osmotic adjustment [6,13,17-19]. Using phosphorus fertilizer decreases the soil phosphorus deficiency, increases the stress-tolerant ability of plants and results in improvement of physiological, morphological, and biochemical processes that lead to better cotton productivity [20-22].

The availability of phosphorus can be increased by coating it with phosphorus-solubilizing bacteria (PSB) and plant growth-promoting bacteria (PGPR) [22-26]. These micro-organisms may also release soluble inorganic phosphates into the soil by decomposing organic compounds rich in phosphate [27]. Phosphate-solubilizing microbes dissolve the soil's phosphorous content by forming organic acids and reduce the $\mathrm{pH}$ of the rhizosphere [28]. Phosphorus-solubilizing bacteria can also produce hormones such as auxins, gibberellins, and cytokinins. Phosphorus-solubilizing bacteria inoculation and plant growth-promoting rhizobacteria help to reduce $50 \%$ of $\mathrm{P}$ fertilizer application without significant crop yield declines [29]. 
The PGPR is a group of bacteria that can be present in the rhizosphere [30]. Plant growth-promoting rhizobacteria clearly affect seed germination and growth of seedlings and thus increase crop yields through phytohormone development, nutrient mobilization, and suppression of plant pathogens [31]. PGPR inoculation with phosphorus induces structural modification, and biochemical and physiological improvements in plant cell walls attributable to salicylic acid, lipopolysaccharides and siderophores synthesis [32]. A number of studies proved that use of arbuscular mycorrhizal fungi (AMF) proved helpful to increase plants' tolerance of drought stress due to extraradical hyphal growth, osmotic adjustment, production of antioxidant enzymes, glomalin-bounded soil structural improvement, and water transport by hyphae [33-35].

Whitaker et al. [36] also found that water supply during the flowering and boll formation process increases the levels of boll initiation, photosynthetic rate, stomatal conductance, and chlorophyll contents. Gerik et al. [37] reported that water-deficit conditions result in a reduction of plant height, leaf area index, stomatal conductance, number of bolls per plant ${ }^{-1}$, boll weight, and quality parameters due to reduced expansion of cells and leaves, and reduced stem elongation in the plant. Tank and Saraf [38] found that phosphorus-solubilizing bacteria (PSB) promote the efficiency of hormones, i.e., auxins, gibberellins, and cytokinins, which improve the crop growth and yield parameters in cotton. Phosphorus-solubilizing bacteria (PSB) coated DAP at the flowering stage could mitigate the negative impact of water shortage by enhancing the growth, quality, and yield parameters of cotton [27]. Zahid et al. [39] found an increase in the total number of bolls per plant, index of the leaf area, net photosynthetic rate, and seed cotton yield with the use of PGPR coated phosphorus. Similar results were found by Majeed et al. [40], who reported increased in growth and yields of cotton with PGPR coated phosphorus. The main hypothesis of this study was that use of inoculation of bacteria could be helpful in the mitigation of drought. The main objective of this study was to compare the effect of PGPR and PSB coated DAP with uncoated DAP and untreated DAP plots.

\section{Materials and Methods}

\subsection{Experiment Site and Soil Characteristics}

A field experiment was conducted on the research area of MNS-University of Agriculture, Multan $\left(32.14^{\circ} \mathrm{N}, 73.65^{\circ} \mathrm{E}\right)$ during kharif season 2019. The climate of the experimental site was arid (Figure 1). The texture of soil was loam with ECe $\left(2.58 \mathrm{dS} \cdot \mathrm{m}^{-1}\right), \mathrm{pHs}(8.60)$, organic matter $(0.91 \%)$, available phosphorus $\left(8.77 \mathrm{mg} \cdot \mathrm{kg}^{-1}\right)$, and exchangeable potassium $\left(250 \mathrm{mg} \cdot \mathrm{kg}^{-1}\right)$.

\subsection{Treatments}

The coated material was in powder form while DAP fertilizers were in granular form. The $60 \mathrm{~g}$ PSB and PGPR, and DAP fertilizer $5 \mathrm{~kg}$, were put in a mechanical mixer and shaken for $30 \mathrm{~min}$ for complete coating of PSB (Bacillus sp.; batch \# PSB190201; date of manufacturing 02/2019; manufacture Koppert Biological System) and PGPR (Rhizobium sp.; batch \# PGPR190201; date of manufacturing 02/2019; manufacture Koppert Biological System) on the fertilizer surface. The irrigation levels (normal and skip) were applied in the main plot while DAP treatments $\left(0,85 \mathrm{~kg} \cdot \mathrm{DAP} \cdot \mathrm{ha}^{-1}\right.$, PSB coated $85 \mathrm{~kg} \cdot \mathrm{DAP} \cdot \mathrm{ha}^{-1}$, and PGPR coated $85 \mathrm{~kg} \cdot \mathrm{DAP} \cdot \mathrm{ha}^{-1}$ were applied in subplots. In normal irrigation plots, twelve irrigations were applied while in skip irrigation plots 9 irrigations were applied. The phosphorus coated with PSB and PGPR was applied through a hand drill at flowering stage. 

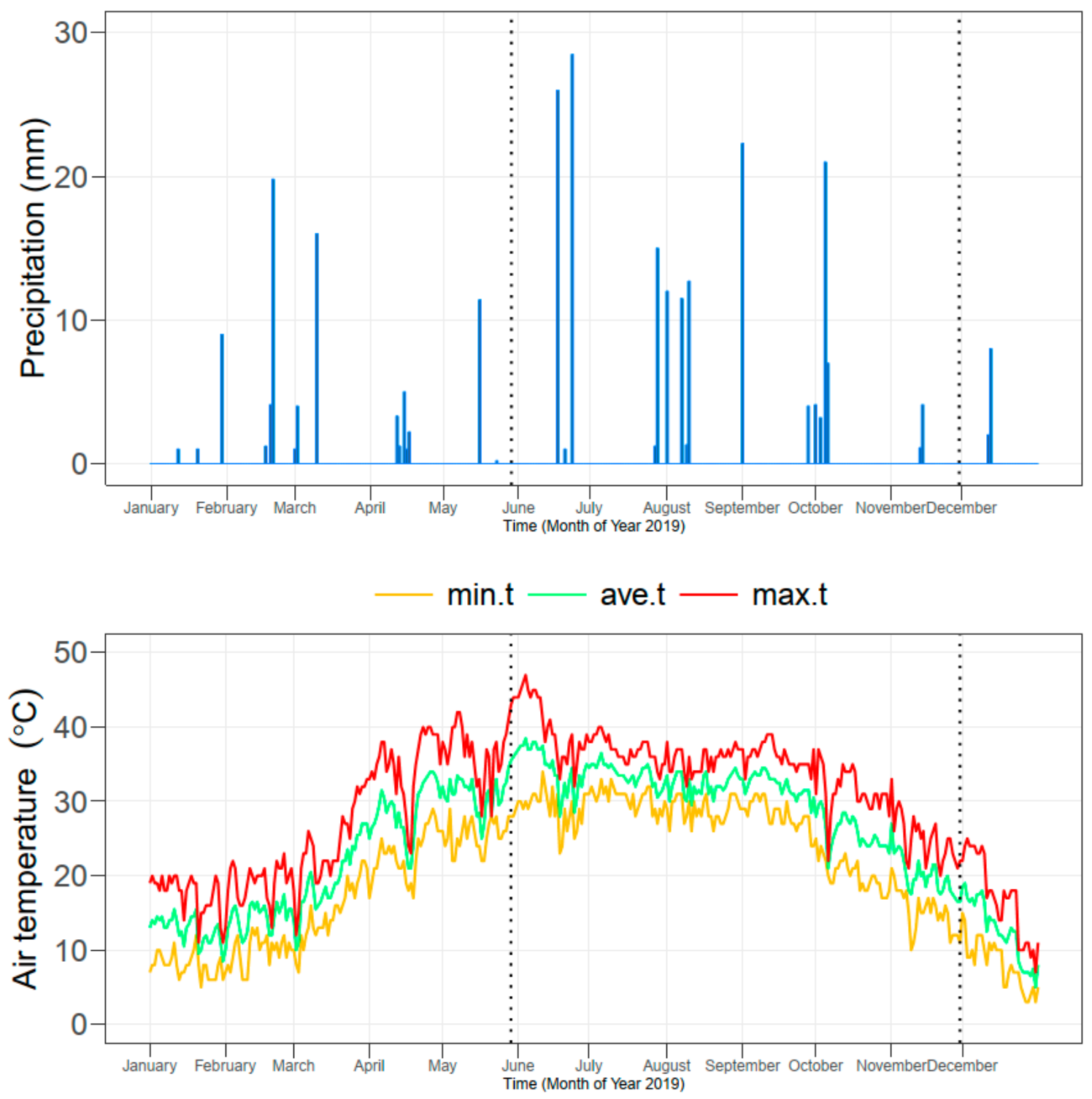

Figure 1. The daily minimum, maximum, and average temperature and rainfall in Multan, Pakistan during the year 2019. The dotted lines show the duration of the cotton crop.

\subsection{Field Preparation}

Seedbeds were prepared 3-4 times by deep ploughing with tractor-mounted cultivator followed by planking. The beds were prepared with a bed shaper. The treatments were applied according to split-plot RCBD design. The irrigation was in main plots and DAP treatment in subplots. Cotton was sown on the bed by dipper method using seed @ $20 \mathrm{~kg} \cdot \mathrm{ha}^{-1}$. Plant-to-plant and row-to-row spacing of 22.5 and $75 \mathrm{~cm}$ was maintained, respectively.

\subsection{Fertilizer Application}

The recommended dose for cotton NK fertilizers (150 and $50 \mathrm{~kg} \mathrm{ha}^{-1}$ ) was applied. All K was applied at sowing while $\mathrm{N}$ was applied in two splits, one at squaring and second on boll formation stage and phosphorus coated with PSB and PGPR was applied at flowering stages. The fertilizer sources used were urea $(46 \% \mathrm{~N})$, diammonium phosphate $\left(18 \% \mathrm{~N}: 46 \% \mathrm{P}_{2} \mathrm{O}_{5}\right)$, and SOP $\left(50 \% \mathrm{~K}_{2} \mathrm{O}\right)$. 


\subsection{Pest Management}

The pesticides acetamaprid $\left(617 \mathrm{~mL} \cdot \mathrm{ha}^{-1}\right)$, imidacloprid $\left(593 \mathrm{~mL} \cdot \mathrm{ha}^{-1}\right.$, and emamectin benzoate (494 $\mathrm{mL} \cdot \mathrm{ha}^{-1}$ ) were used to control whitefly, jassid, thrips, and bollworm. Weed control was done by using labor and application of weedicide (Dualgold). Cotton picking was done when more than $90 \%$ of bolls were matured. Harvesting was done on 24 November 2019.

\subsection{Harvesting and Data Collection}

Plant height was taken with scale at maturity. At the time of picking, number of sympodial branches per plant ${ }^{-1}$, number of monopodial branches per plant ${ }^{-1}$, number of nodes per plant ${ }^{-1}$ and number of bolls per plant ${ }^{-1}$ of five plants were selected randomly from every plot. The seed cotton yield ha ${ }^{-1}$ was measured by using the seed cotton obtained from net plot area. Seed cotton yield of each plot was converted into $\mathrm{kg} \mathrm{ha}^{-1}$. Photosynthetic rate, stomatal conductance, and transpiration rate from each of the five randomly selected plants were measured by using portable infrared gas analyzer (IRGA) (CID Bio-Science, Inc, Camas, WA, USA, photosynthetic system CI-340). Leaf area index was calculated by using the following equation from Watson [41].

$$
\mathrm{LAI}=\frac{\text { Leaf area per plant }\left(\mathrm{cm}^{2}\right)}{\text { Land area per plant }\left(\mathrm{cm}^{2}\right)}
$$

\subsection{Chlorophyll Contents and Total Dry Matter}

Chlorophyll contents were measured with the help of SPAD-502. The whole plant was weighed via electric balance to measure TDM. Fiber length is the size of fiber in millimeters (mm).

\subsection{Crop Growth Rate}

Crop growth rate (CGR) was computed at each sample date. Final calculations were made by using the below equation and represented as $\mathrm{g} \mathrm{m}^{-2}$ day $^{-1}$.

$$
\mathrm{CGR}=\frac{\mathrm{W}_{2}-\mathrm{W}_{1}}{\mathrm{t}_{2}-\mathrm{t}_{1}}
$$

\subsection{Statistical Analyses}

The collected data of growth, yield, and fiber quality attributes of the cotton crop were analyzed by using a linear model in R software version 4.0.0 [42] and Origin 2020b. The effect of treatments on all measured parameters was tested within normal and skip irrigation separately. The means of the treatments were separated by least-square means and the adjusted Tukey multiple comparison test at $p<0.05$. The least-square means and the adjusted multiple comparison procedure was adopted by using "emmeans" package in R software [43].

\section{Results}

\subsection{Plant Height, Sympodial Branches Plant ${ }^{-1}$, and Nodes Plant ${ }^{-1}$}

Overall, normal irrigation showed higher response on plant height as compared to skip irrigation. All treatment of DAP application showed higher response as compared to control in both normal and skip irrigation. The response of PGPR was higher as compared to PSB coated DAP, DAP, and control (no DAP). In normal irrigation, PGPR coated DAP showed 30.87\%, 19.59\%, and 9.20\% higher plant height as compared to control, DAP, and PSB coated DAP, respectively, while in skip irrigation, PGPR coated DAP increased plant height $39.06 \%, 25.26 \%$, and $12.26 \%$ as compared to control, uncoated DAP, and PSB coated phosphorus, respectively (Table 1 ). 
Table 1. Impact of phosphorus coated diammonium phosphate (DAP) on plant height, sympodial branches, and number of nodes per plant of cotton under normal and skip irrigation. The values are the mean of three replications. Within irrigation levels, the values with the same letter (s) are statistically non-significant at $p<0.05$.

\begin{tabular}{ccccccc}
\hline \multirow{2}{*}{$\begin{array}{c}\text { Phosphorus } \\
\text { Application }\end{array}$} & \multicolumn{2}{c}{ Plant Height $\mathbf{( c m )}$} & \multicolumn{2}{c}{ Sympodial Branches Plant } & \multicolumn{2}{c}{ Number of Nodes Plant $^{-1}$} \\
\cline { 2 - 7 } & $\begin{array}{c}\text { Normal } \\
\text { Irrigation }\end{array}$ & Skip Irrigation & $\begin{array}{c}\text { Normal } \\
\text { Irrigation }\end{array}$ & Skip Irrigation & $\begin{array}{c}\text { Normal } \\
\text { Irrigation }\end{array}$ & Skip Irrigation \\
\hline Control (No DAP) & $87.97 \pm 1.68 \mathrm{a}$ & $61.43 \pm 2.47 \mathrm{a}$ & $22 \pm 1.00 \mathrm{a}$ & $18.00 \pm 1.00 \mathrm{a}$ & $30.00 \pm 1.00 \mathrm{a}$ & $19.67 \pm 0.58 \mathrm{a}$ \\
DAP & $96.27 \pm 0.50 \mathrm{~b}$ & $68.20 \pm 2.04 \mathrm{~b}$ & $26 \pm 1.00 \mathrm{~b}$ & $21.33 \pm 0.58 \mathrm{~b}$ & $31.33 \pm 0.58 \mathrm{~b}$ & $21.00 \pm 0.01 \mathrm{~b}$ \\
PGPR Coated DAP & $115.13 \pm 4.75 \mathrm{~d}$ & $85.43 \pm 1.52 \mathrm{~d}$ & $31 \pm 1.73 \mathrm{~d}$ & $27.00 \pm 1.00 \mathrm{~d}$ & $34.00 \pm 1.00 \mathrm{~d}$ & $23.33 \pm 0.58 \mathrm{c}$ \\
PSB Coated DAP & $105.43 \pm 2.47 \mathrm{c}$ & $76.10 \pm 2.14 \mathrm{c}$ & $28.67 \pm 1.53 \mathrm{c}$ & $24.33 \pm 0.58 \mathrm{c}$ & $32.33 \pm 0.58 \mathrm{c}$ & $22.00 \pm 0.01 \mathrm{~b}$ \\
\hline
\end{tabular}

The same results were found on sympodial branches. In normal irrigation, PGPR coated DAP showed $40.72 \%, 19.15 \%$, and $8.47 \%$ higher sympodial branches per plant $^{-1}$ as compared to no DAP, DAP, and PSB coated DAP, respectively, while in skip irrigation, PGPR coated DAP increased sympodial branches per plant ${ }^{-1} 50.01 \%, 26.58 \%$, and $10.97 \%$ as compared to control, DAP, and PSB coated phosphorus, respectively (Table 1).

In normal irrigation, PGPR coated DAP showed $13.33 \%, 8.52 \%$, and $5.16 \%$ higher number of nodes per plant ${ }^{-1}$ as compared to control, DAP, and PSB coated DAP, respectively, while in skip irrigation, PGPR coated DAP increased number of nodes per plant ${ }^{-1} 18.60 \%, 11.09 \%$, and $6.04 \%$ as related to control, DAP, and PSB coated phosphorus, respectively (Table 1).

\subsection{Bolls Plant ${ }^{-1}$, Boll Weight, and Seed Cotton Yield}

The normal irrigation showed higher number of bolls per plant ${ }^{-1}$, boll weight, and seed cotton yield over skip irrigation in all DAP treatments. The PGPR DAP coated application effect was more as compared to PSB coated DAP in both normal and skip irrigation regimes. In normal irrigation, PGPR coated DAP showed $51.57 \%, 36.21 \%$, and $18.98 \%$ more total bolls per plant ${ }^{-1}$ as compared to control, DAP, and PSB coated DAP, respectively, while in skip irrigation, PGPR coated DAP increased the number of bolls plant ${ }^{-1} 79.43 \%, 56.38 \%$, and $27.06 \%$ as related to control, DAP, and PSB coated DAP, respectively (Table 2).

Table 2. Impact of phosphorus coated diammonium phosphate (DAP) on number of bolls per plant, boll weight, and seed cotton yield of cotton under normal and skip irrigation.

\begin{tabular}{ccccccc}
\hline \multirow{2}{*}{$\begin{array}{c}\text { Phosphorus } \\
\text { Application }\end{array}$} & \multicolumn{2}{c}{ No. of Bolls Plant ${ }^{-1}$} & \multicolumn{2}{c}{ Boll Weight (g) } & \multicolumn{2}{c}{ Seed Cotton Yield (kg ha $\mathbf{- 1})^{\text {Normal }}$} \\
\cline { 2 - 7 } & Irrigation & Skip Irrigation & $\begin{array}{c}\text { Normal } \\
\text { Irrigation }\end{array}$ & Skip Irrigation & $\begin{array}{c}\text { Normal } \\
\text { Irrigation }\end{array}$ & Skip Irrigation \\
\hline Control (No DAP) & $20.67 \pm 1.53 \mathrm{a}$ & $11.33 \pm 0.58 \mathrm{a}$ & $2.36 \pm 0.16 \mathrm{a}$ & $2.03 \pm 0.06 \mathrm{a}$ & $2153 \pm 47.29 \mathrm{a}$ & $1555.67 \pm 46.2 \mathrm{a}$ \\
DAP & $23.00 \pm 1.00 \mathrm{~b}$ & $13.00 \pm 1.00 \mathrm{a}$ & $2.53 \pm 0.13 \mathrm{~b}$ & $2.15 \pm 0.04 \mathrm{~b}$ & $2346 \pm 33.56 \mathrm{~b}$ & $1691.33 \pm 45.39 \mathrm{~b}$ \\
PGPR Coated DAP & $31.33 \pm 1.15 \mathrm{~d}$ & $20.33 \pm 1.15 \mathrm{c}$ & $2.80 \pm 0.06 \mathrm{c}$ & $2.28 \pm 0.06 \mathrm{c}$ & $2694 \pm 49.49 \mathrm{~d}$ & $1950.67 \pm 49.66 \mathrm{~d}$ \\
PSB Coated DAP & $26.33 \pm 0.58 \mathrm{c}$ & $16.00 \pm 1.00 \mathrm{~b}$ & $2.66 \pm 0.11 \mathrm{bc}$ & $2.20 \pm 0.03 \mathrm{~b}$ & $2511 \pm 41.49 \mathrm{c}$ & $1849.33 \pm 52.2 \mathrm{c}$ \\
\hline
\end{tabular}

In normal irrigation, PGPR coated DAP showed 18.64\%, 10.67\%, and 5.26\% higher boll weight as compared to control, DAP, and PSB coated DAP respectively, while in skip irrigation, PGPR coated DAP increased boll weight $12.31 \%, 6.04 \%$, and $3.63 \%$ as related to control, DAP, and PSB coated phosphorus, respectively (Table 2).

In normal irrigation, PGPR coated DAP showed $25.12 \%, 14.88 \%$, and $7.27 \%$ higher cotton yield as related to control, DAP, and PSB coated DAP, respectively, while in skip irrigation, PGPR coated DAP increased seed cotton yield $25.39 \%, 15.33 \%$, and $5.47 \%$ as related to control, DAP, and PSB coated phosphorus respectively (Table 2). 


\subsection{Photosynthetic Rate, Stomatal Conductance, and Transpiration Rate}

The normal irrigation showed higher photosynthetic rate, stomatal conductance, and transpiration rate over skip irrigation in all DAP treatments. The PGPR DAP coated application effect was more as compared to PSB coated DAP in both normal and skip irrigation regimes. In normal irrigation, PGPR coated DAP showed $28.05 \%, 17.45 \%$, and $6.90 \%$ higher photosynthetic rate as compared to control, DAP, and PSB coated phosphorus respectively, while in skip irrigation, PGPR coated DAP increased photosynthetic rate $24.29 \%, 14.52 \%$, and $9.26 \%$ as related to control, DAP, and PSB coated phosphorus, respectively (Figure 2).
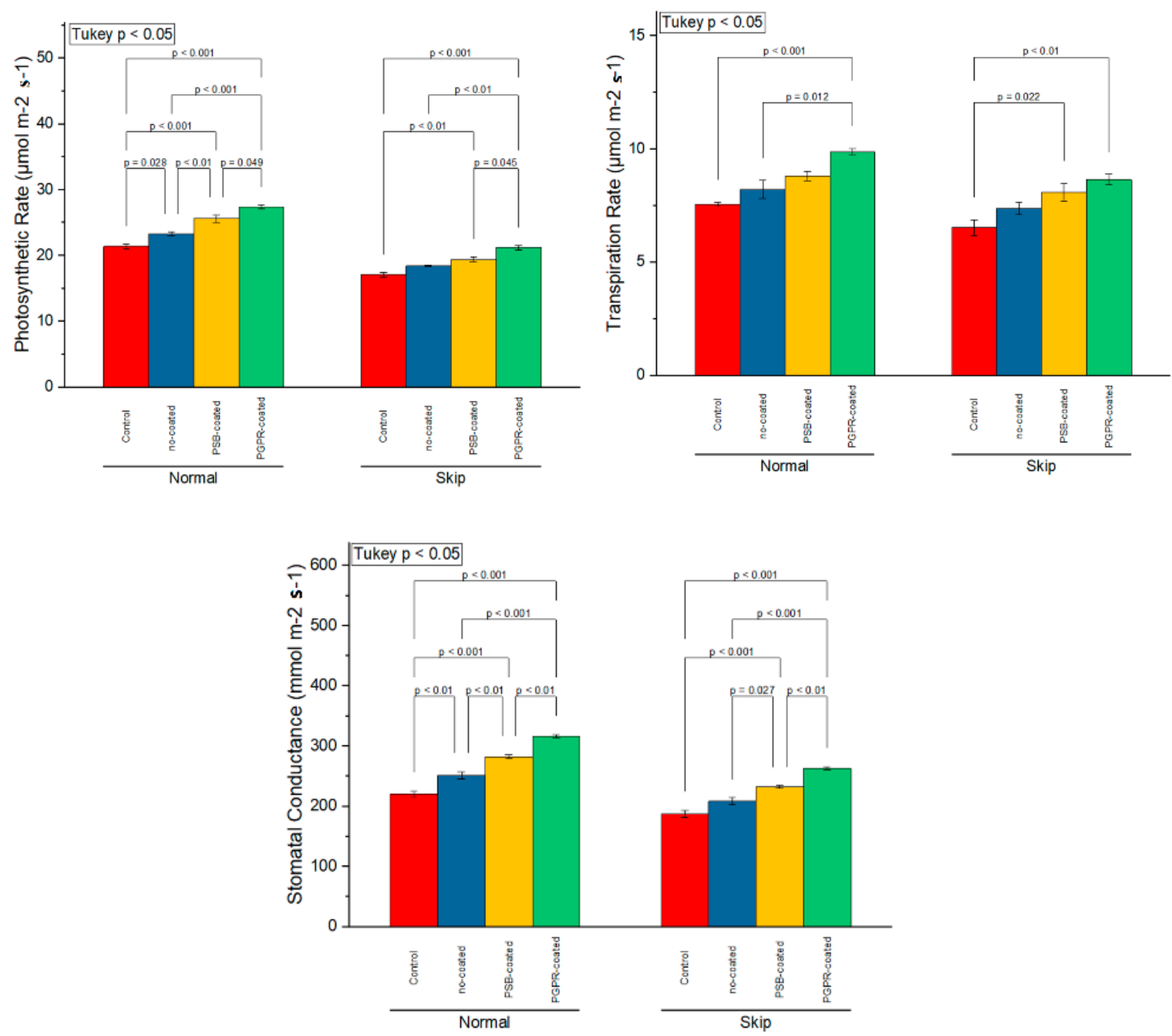

Figure 2. Impact of phosphorus coated diammonium phosphate (DAP) on photosynthetic rate, stomatal conductance, and transpiration rate of cotton under normal and skip irrigation. The values are the mean of three replications. Bars having no $p$-values are statistically non-significant at $\alpha<0.05$.

In normal irrigation, PGPR coated DAP showed 43.66\%, 25.94\%, and 12.02\% higher stomatal conductance as compared to control, DAP, and PSB coated DAP respectively, while in skip irrigation, PGPR coated DAP increased stomatal conductance $40.37 \%, 26.26 \%$, and $13.21 \%$ as compared to control, DAP, and PSB coated DAP, respectively (Figure 2).

In normal irrigation, PGPR coated DAP showed $30.99 \%, 20.31 \%$, and $12.38 \%$ higher transpiration rate as compared to control, DAP and PSB coated phosphorus respectively, while in skip irrigation, PGPR coated DAP increased transpiration rate $32.46 \%, 17.20 \%$, and $7.05 \%$ as related to control, DAP and PSB coated phosphorus, respectively (Figure 2). 


\subsection{Leaf Area Index, Chlorophyll Contents, and Total Dry Matter}

The normal irrigation showed higher leaf area index, chlorophyll contents, and total dry matter over skip irrigation in all DAP treatments. The PGPR DAP coated application effect was more as compared to PSB coated DAP in both normal and skip irrigation regimes. In normal irrigation, PGPR coated DAP showed $30.01 \%, 15.55 \%$, and $6.77 \%$ higher leaf area index as compared to control, DAP and PSB coated phosphorus respectively, while in skip irrigation, PGPR coated DAP increased leaf area index $32.35 \%, 20.64 \%$, and $32.50 \%$ as related to control, DAP, and PSB coated phosphorus, respectively (Table 3).

Table 3. Impact of phosphorus coated diammonium phosphate (DAP) on leaf area index, chlorophyll contents, and total dry matter of cotton under normal and skip irrigation.

\begin{tabular}{ccccccc}
\hline \multirow{2}{*}{$\begin{array}{c}\text { Phosphorus } \\
\text { Application }\end{array}$} & \multicolumn{2}{c}{ Leaf Area Index } & \multicolumn{2}{c}{$\begin{array}{c}\text { Chlorophyll Contents (SPAD } \\
\text { Value) }\end{array}$} & \multicolumn{2}{c}{ Total Dry Matter (g Plant $^{-1}$ ) } \\
\cline { 2 - 7 } & $\begin{array}{c}\text { Normal } \\
\text { Irrigation }\end{array}$ & Skip Irrigation & $\begin{array}{c}\text { Normal } \\
\text { Irrigation }\end{array}$ & Skip Irrigation & $\begin{array}{c}\text { Normal } \\
\text { Irrigation }\end{array}$ & Skip Irrigation \\
\hline Control (No DAP) & $4.00 \pm 0.10 \mathrm{a}$ & $3.40 \pm 0.10 \mathrm{a}$ & $49.70 \pm 0.8 \mathrm{a}$ & $45.91 \pm 1.56 \mathrm{a}$ & $320.5 \pm 10.27 \mathrm{a}$ & $255.8 \pm 13.22 \mathrm{a}$ \\
DAP & $4.50 \pm 0.10 \mathrm{~b}$ & $3.73 \pm 0.06 \mathrm{~b}$ & $53.47 \pm 2.78 \mathrm{ab}$ & $54.04 \pm 4.91 \mathrm{a}$ & $371.26 \pm 10.25 \mathrm{~b}$ & $281.48 \pm 10.99 \mathrm{a}$ \\
PGPR Coated DAP & $5.20 \pm 0.10 \mathrm{~d}$ & $4.50 \pm 0.10 \mathrm{~d}$ & $53.57 \pm 3.18 \mathrm{ab}$ & $57.64 \pm 11.34 \mathrm{a}$ & $442.31 \pm 20.08 \mathrm{~d}$ & $358.32 \pm 8.43 \mathrm{c}$ \\
PSB Coated DAP & $4.87 \pm 0.06 \mathrm{c}$ & $3.40 \pm 0.10 \mathrm{a}$ & $55.34 \pm 2.12 \mathrm{~b}$ & $57.67 \pm 4.31 \mathrm{a}$ & $406.42 \pm 14.2 \mathrm{c}$ & $326.6 \pm 14.39 \mathrm{~b}$ \\
\hline
\end{tabular}

The values are the mean of three replications. Within irrigation levels, the values with the same letter (s) are statistically non-significant at $p<0.05$.

In normal irrigation, PGPR coated DAP showed $11.34 \%, 3.49 \%$, and 3.30\% higher chlorophyll content as compared to control, DAP and PGPR coated DAP, respectively, while in skip irrigation, PGPR coated DAP increased chlorophyll content $25.48 \%, 6.71 \%$, and $0.05 \%$ as compared to control, DAP and PGPR coated DAP, respectively (Table 3 ).

In normal irrigation, PGPR coated DAP showed $38.01 \%, 19.13 \%$, and $8.83 \%$ higher total dry matter as compared to control, DAP, and PSB coated DAP, respectively while in skip irrigation, PGPR coated DAP increased total dry matter $40.07 \%, 27.29 \%$, and $9.71 \%$ as compared to control, DAP and PSB coated DAP respectively (Table 3).

\subsection{Fiber Length, Fiber Strength, and Fiber Fineness}

The normal irrigation showed higher fiber length, fiber strength, and fiber fineness over skip irrigation in all DAP treatments. The PGPR DAP coated application effect was more as compared to PSB coated DAP in both normal and skip irrigation regimes. In normal irrigation, PGPR coated DAP showed $15.63 \%, 8.21 \%$, and $4.52 \%$ higher fiber length as compared to control, DAP, and PSB coated phosphorus, respectively, while in skip irrigation, PGPR coated DAP increased fiber length $17.30 \%$, $12.83 \%$, and $3.12 \%$ as related to control, DAP, and PSB coated phosphorus, respectively (Figure 3).

In normal irrigation, PGPR coated DAP showed $18.32 \%, 12.72 \%$, and $8.30 \%$ higher fiber strength as compared to control, DAP, and PSB coated phosphorus, respectively while in skip irrigation, PGPR coated DAP increased fiber strength $20.14 \%, 13.24 \%$, and $5.55 \%$ as related to control, DAP and PSB coated phosphorus, respectively (Figure 3).

In normal irrigation, PGPR coated DAP showed 19.35\%, 9.81\%, and $3.21 \%$ higher fiber fineness as compared to control, DAP, and PSB coated phosphorus, respectively, while in skip irrigation, PGPR coated DAP increased fiber fineness $23.80 \%, 15.72 \%$, and $5.97 \%$ as compared to control, DAP and PSB coated phosphorus, respectively (Figure 3). 

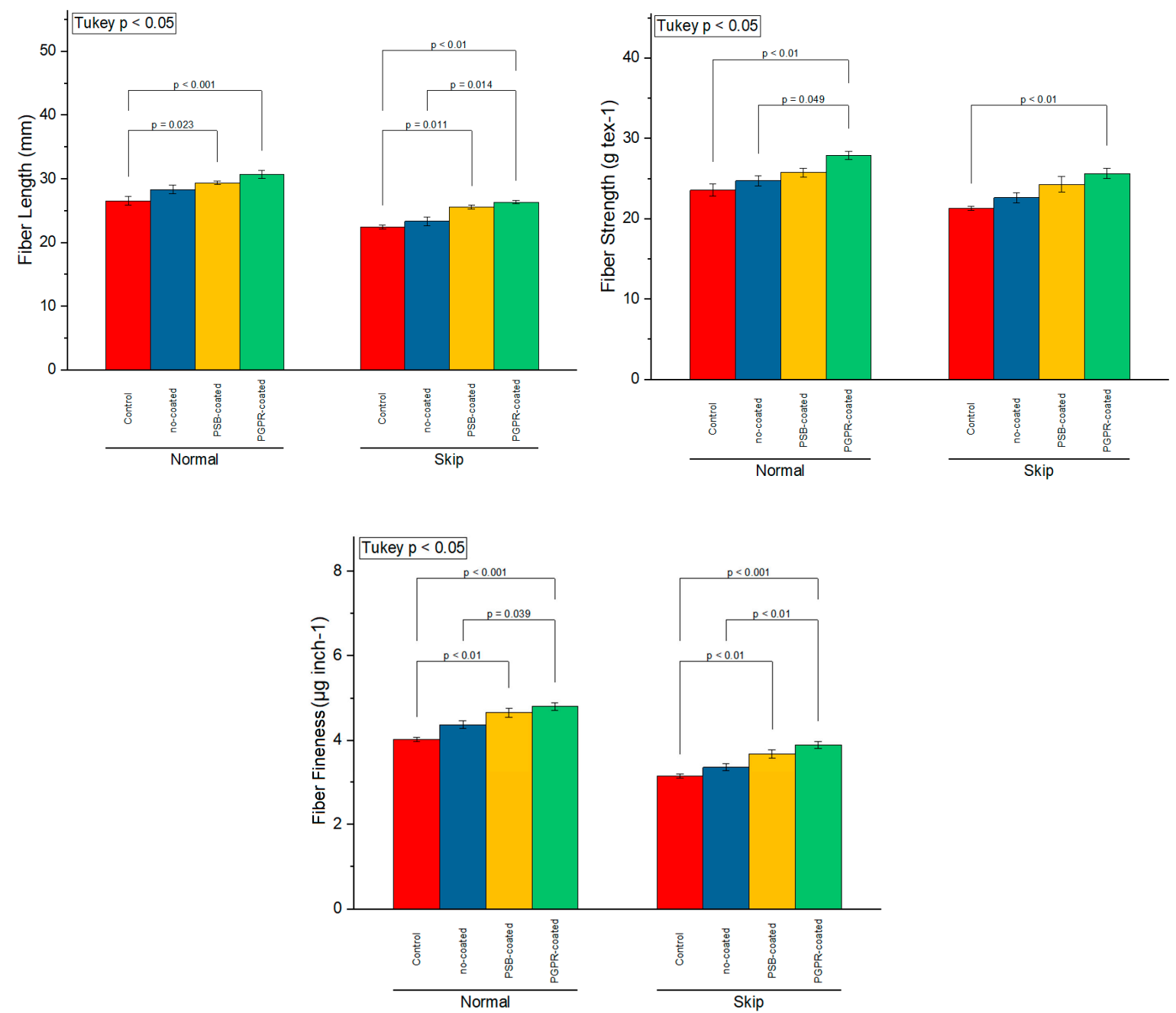

Figure 3. Impact of phosphorus coated diammonium phosphate (DAP) on fiber length, fiber strength, and fiber fineness of cotton under normal and skip irrigation. The values are the mean of three replications. Bars having no $p$-values are statistically non-significant at $p<0.05$.

\subsection{Uniformity Index and Crop Growth Rate}

The normal irrigation showed higher uniformity index, number of microbes, and crop growth matter over skip irrigation in all DAP treatments. The PGPR DAP coated application effect was more as compared to PSB coated DAP in both normal and skip irrigation regimes. In normal irrigation, PGPR coated DAP showed $6.57 \%, 3.80 \%$, and $1.55 \%$ higher uniformity index as compared to control, DAP and PSB coated phosphorus, respectively, while in skip irrigation, PGPR coated DAP increased uniformity index $8.51 \%, 6.05 \%$, and $3.21 \%$ as related to control, DAP and PSB coated phosphorus, respectively (Figure 4). 

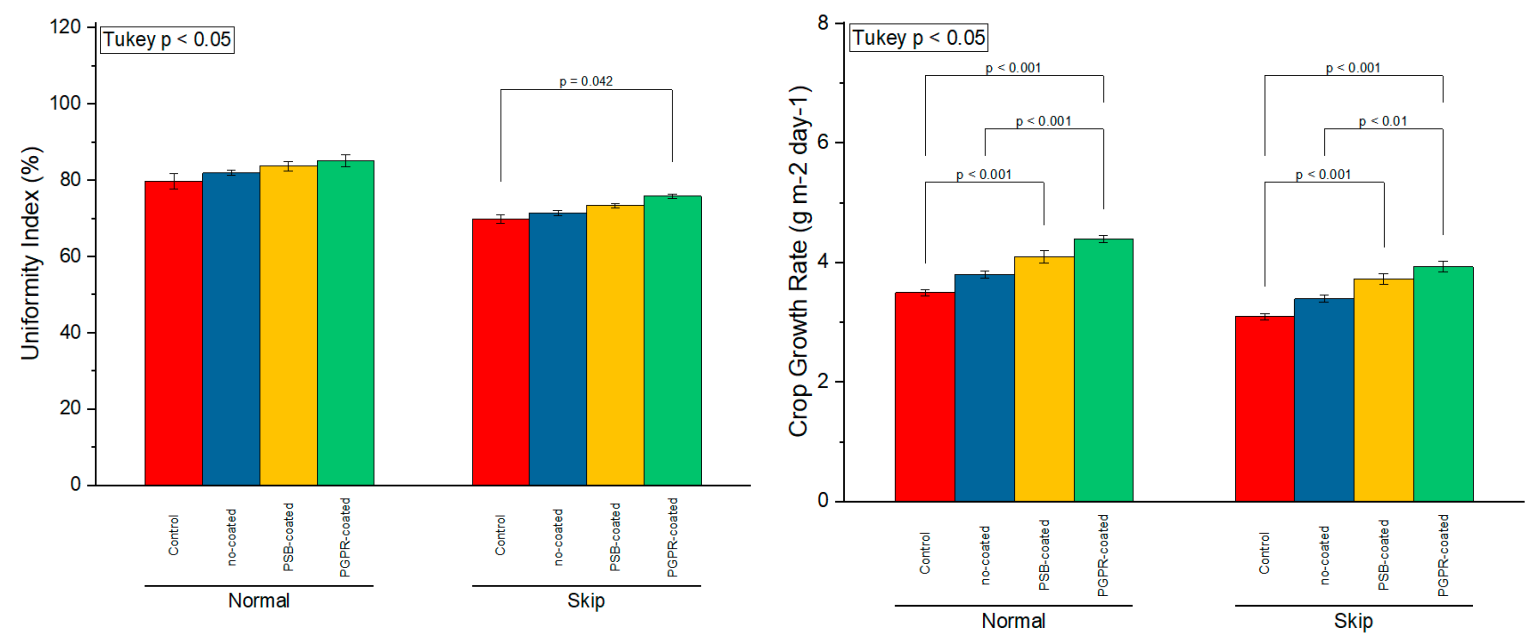

Figure 4. Impact of phosphorus coated diammonium phosphate (DAP) on uniformity index and crop growth rate of cotton under normal and skip irrigation. The values are the mean of three replications. Bars having no $p$-values are statistically non-significant at $p<0.05$.

In normal irrigation, PGPR coated DAP showed $25.71 \%, 15.78 \%$, and $7.31 \%$ higher crop growth rate as compared to control, DAP, and PSB coated phosphorus, respectively while in skip irrigation, PGPR coated DAP increased crop growth rate $27.77 \%, 15.58 \%$, and $5.36 \%$ as related to control, DAP, and PSB coated phosphorus, respectively (Figure 4).

\section{Discussion}

The current study was conducted to evaluate the effect of PGPR and PSB coated DAP on cotton growth, yield, and fiber quality attributes under normal and skip irrigation conditions in Multan, Pakistan. The results revealed that all DAP treatments performed better where normal irrigation was applied as compared to skip irrigation. In addition, DAP applied treatments (DAP, PGPR coated, and PSB coated) showed higher response as compared to control (no DAP). Further, PGPR coated DAP treatments' effect on the cotton productivity was higher as compared to PSB coated DAP.

The normal irrigation showed improved plant height, nodes per plant ${ }^{-1}$, bolls per plant ${ }^{-1}$, boll weight, seed cotton yield, photosynthetic rate, stomatal conductance, transpiration rate, leaf area index, chlorophyll contents, and total dry matter. Sufficient supply of water may be the reason for increased growth, and physiological, quality, and yield attributes of cotton crop in the current study. The greater availability of water usually increases nutrient availability and uptake, as reported in a number of studies. Gwathmey et al. [44] reported an increase in leaf area index, total dry matter, and seed cotton yield in normal irrigation due to the availability of essential nutrients to the plant. Similar results were reported by Pettigrew and Meredith [45]; that a proper amount of irrigation increased plant height, boll weight, and nodes per plant ${ }^{-1}$.

In another study, Whitaker et al. [36] found that water supply during flowering and boll formation processes could increase levels of boll initiation, photosynthetic rate, stomatal conductance, and chlorophyll contents. The lower values of growth parameters such as the index of the leaf area, physiological features such as net photosynthetic rate, stomatal conductance, and chlorophyll content and cotton yield parameters in the current study might be due to production of reactive oxygen species within plants which affected the plant cell organelles, accumulation of dry matter, and uptake of water and essential nutrients. These findings are in line with the existing literature. Gerik et al. [37] reported that water-deficit conditions resulted in reduction of plant height, leaf area index, stomatal conductance, bolls per plant ${ }^{-1}$, boll weight, and fiber quality parameters due to reduced expansion of cells and leaves and reduced stem elongation. 
In another study, Jaleel et al. [46] reported that water stress induced a reduction to the whole plant leaf area index by decreasing the leaf number rather than the leaf size. Similar results were reported by Lawlor and Cornic [47]; that water deficit stress in cotton reduced photosynthetic rates and chlorophyll content. Water deficit could affect all growth, physiology, and yield parameters by various mechanisms related to osmotic oxidative damage at the cellular level. The oxidative damage decreases the plant's capacity to divide cells in a water stress environment [48].

The application of PGPR coated DAP showed positive effects on plant height, sympodial branches per plant ${ }^{-1}$, nodes per plant ${ }^{-1}$, bolls per plant ${ }^{-1}$, boll weight, seed cotton yield, photosynthetic rate, stomatal conductance, transpiration rate, leaf area index, chlorophyll contents, and total dry matter as compared to other treatments in both normal and skip irrigation conditions. These findings are in line with the literature. Yasmin et al. [49] reported that PGPR coated phosphorus increased the cotton yield due to a greater number of monopodial branches and crop growth rate. Zahid et al. [39] found increased total cotton bolls per plant ${ }^{-1}$, leaf area index, net photosynthetic rate, and seed cotton where PGPR coated phosphorus was applied. Shao et al. [50] after 12 weeks of AMF inoculation found 15.12\% to $40.23 \%$ increase in root mycorrhizal colonization along with an increase in plant height, root and shoot biomass, and leaf area in tea plants.

Similarly, Majeed et al. [40] reported increased growth and yield parameters of cotton with the use of PGPR coated phosphorus. In another study, Gomare et al. [51] reported higher cotton plant height, total dry matter, bolls per plant ${ }^{-1}$, nodes per plant ${ }^{-1}$, photosynthetic rate, and seed cotton yield were increased by the application of PSB coated DAP. Phosphorus solubilizing bacteria (PSB) promotes the efficiency of hormones, i.e., auxins, gibberellins, and cytokinins, which could improve the crop growth and yield parameters of cotton [38]. Phosphorus solubilizing bacteria (PSB) coated DAP at the flowering stage could mitigate the negative impact of water shortage by enhancing the growth, quality, and yield parameters of cotton [27].

\section{Conclusions}

The application of PGPR and PSB coated DAP showed promising results on the growth, yield, and fiber quality attributes of cotton. However, cotton productivity was higher with PGPR and PSB coated diammonium phosphate where normal irrigation was applied as compared to skip irrigation. In addition, PGPR coated results were better as compared to PSB coating of DAP in the current study. Therefore, it is recommended to use PGPR coated DAP with normal irrigation to get higher yields of cotton in Multan, Pakistan. However, longer studies in different locations are suggested to get a sustainable increase in cotton productivity with the recommended treatments.

Author Contributions: Conceptualization, M.M., M.A.; formal analysis, F.A., M.I., G.S.H.; data curation, R.M.I., G.S.H., S.D.; writing-original draft preparation, K.S., F.A., M.A., R.M.I., M.I., S.D.; writing-review and editing, R.D., S.F., S.D., H.M.A., M.Z.M.S., A.E.S., G.S.H., I.A.A., A.A.-h., T.Z., M.H.-u.-R.; funding acquisition, I.A.A., A.A.-h. All authors have read and agreed to the published version of the manuscript.

Funding: Researchers Supporting Project number RSP-2020/176, King Saud University, Riyadh, Saudi Arabia.

Acknowledgments: The authors would like to extend their sincere appreciation to the Researchers Supporting Project number (RSP-2020/176), King Saud University, Riyadh, Saudi Arabia. We also acknowledge Ijaz Ahmad (Deputy Manager R\&D) and Muhammad Asif Ali (Head Research), R\&D Wing, Engro Fertilizer Limited, Pakistan for providing PSB and PGPR coated DAP.

Conflicts of Interest: The authors declare no conflict of interest.

\section{References}

1. GOP. Economic Survey of Pakistan; Finance Division, Economic Advisory Wing; Government of Pakistan: Islamabad, Pakistan, 2013. Available online: http://www.finance.gov.pk/survey_1314.html (accessed on 5 March 2017).

2. GOP. Agricultural Statistics of Pakistan. Available online: http://dai.agripunjab.gov.pk/system/files/ OnionPlan2019-20_0.pdf (accessed on 23 September 2019). 
3. Danish, S.; Kiran, S.; Fahad, S.; Ahmad, N.; Ali, M.A.; Tahir, F.A.; Rasheed, M.K.; Shahzad, K.; Li, X.; Wang, D.; et al. Alleviation of chromium toxicity in maize by Fe fortification and chromium tolerant ACC deaminase producing plant growth promoting rhizobacteria. Ecotoxicol. Environ. Saf. 2019, 185, 109706. [CrossRef] [PubMed]

4. Shah, A.A.; Bibi, F.; Hussain, I.; Yasin, N.A.; Akram, W.; Tahir, M.S.; Ali, H.M.; Salem, M.Z.M.; Siddiqui, M.H.; Danish, S.; et al. Synergistic effect of bacillus thuringiensis iags 199 and putrescine on alleviating cadmium-induced phytotoxicity in capsicum annum. Plants 2020, 9, 1512. [CrossRef] [PubMed]

5. Adnan, M.; Fahad, S.; Zamin, M.; Shah, S.; Mian, I.A.; Danish, S.; Zafar-ul-Hye, M.; Battaglia, M.L.; Naz, R.M.M.; Saeed, B.; et al. Coupling Phosphate-Solubilizing Bacteria with Phosphorus Supplements Improve Maize Phosphorus Acquisition and Growth under Lime Induced Salinity Stress. Plants 2020, 9, 900. [CrossRef] [PubMed]

6. Zafar-ul-Hye, M.; Tahzeeb-ul-Hassan, M.; Abid, M.; Fahad, S.; Brtnicky, M.; Dokulilova, T.; Datta, R.; Danish, S. Potential role of compost mixed biochar with rhizobacteria in mitigating lead toxicity in spinach. Sci. Rep. 2020, 10, 69183. [CrossRef]

7. Ullah, A.; Ali, M.; Shahzad, K.; Ahmad, F.; Iqbal, S.; Habib, M.; Rahman, U.; Ahmad, S.; Iqbal, M.M. Impact of Seed Dressing and Soil Application of Potassium Humate on Cotton Plants Productivity and Fiber Quality. Plants 2020, 9, 1444. [CrossRef]

8. Rafiullah, R.; Tariq, M.; Khan, F.; Shah, A.; Fahad, S.; Wahid, F.; Ali, J.; Adnan, M.; Ahmad, M.; Irfan, M.; et al. Effect of micronutrients foliar supplementation on the production and eminence of plum. Qual. Assur. Saf. Crop. Foods 2020, 12, 32-40. [CrossRef]

9. Hejnák, V.; Tatar, Ö.; Atasoy, G.D.; Martinková, J.; Çelen, A.E.; Hnilička, F.; Skalický, M. Growth and photosynthesis of Upland and Pima cotton: Response to drought and heat stress. Plant Soil Environ. 2016, 61, 507-514. [CrossRef]

10. Plaut, Z.; Carmi, A.; Grava, A. Cotton root and shoot responses to subsurface drip irrigation and partial wetting of the upper soil profile. Irrig. Sci. 1996, 16, 107-113. [CrossRef]

11. Guinn, G.; Dunlap, J.R.; Brummett, D.L. Influence of Water Deficits on the Abscisic Acid and Indole-3-Acetic Acid Contents of Cotton Flower Buds and Flowers. Plant Physiol. 1990, 93, 1117-1120. [CrossRef]

12. Makbul, S.; Güler, N.S.; Durmuş, N.; Güven, S. Changes in anatomical and physiological parameters of soybean under drought stress. Turk. J. Bot. 2011, 35, 369-377.

13. Danish, S.; Zafar-Ul-Hye, M.; Hussain, S.; Riaz, M.; Qayyum, M.F. Mitigation of drought stress in maize through inoculation with drought tolerant ACC deaminase containing PGPR under axenic conditions. Pak. J. Bot. 2020, 52, 49-60. [CrossRef]

14. Danish, S.; Zafar-ul-Hye, M.; Mohsin, F.; Hussain, M. ACC-deaminase producing plant growth promoting rhizobacteria and biochar mitigate adverse effects of drought stress on maize growth. PLOS ONE 2020, 15, e0230615. [CrossRef] [PubMed]

15. Danish, S.; Zafar-ul-Hye, M. Combined role of ACC deaminase producing bacteria and biochar on cereals productivity under drought. Phyton 2020, 89, 217-227. [CrossRef]

16. Danish, S.; Zafar-ul-Hye, M. Co-application of ACC-deaminase producing PGPR and timber-waste biochar improves pigments formation, growth and yield of wheat under drought stress. Sci. Rep. 2019, 9, 5999. [CrossRef]

17. Garg, B.K.; Burman, U.; Kathju, S. The influence of phosphorus nutrition on the physiological response of moth bean genotypes to drought. J. Plant Nutr. Soil Sci. 2004, 167, 503-508. [CrossRef]

18. Danish, S.; Ameer, A.; Qureshi, T.I.; Younis, U.; Manzoor, H.; Shakeel, A.; Ehsanullah, M. Influence of biochar on growth and photosynthetic attributes of Triticum aestivum L. under half and full irrigation. Int. J. Biosci. 2014, 5, 101-108.

19. Danish, S.; Zafar-ul-Hye, M.; Fahad, S.; Saud, S.; Brtnicky, M.; Hammerschmiedt, T.; Datta, R. Drought Stress Alleviation by ACC Deaminase Producing Achromobacter xylosoxidans and Enterobacter cloacae, with and without Timber Waste Biochar in Maize. Sustainability 2020, 12, 6286. [CrossRef]

20. Cortina, J.; Vilagrosa, A.; Trubat, R. The role of nutrients for improving seedling quality in drylands. New For. 2013, 44, 719-732. [CrossRef]

21. Rafiullah, R.; Khan, M.J.; Muhammad, D.; Fahad, S.; Adnan, M.; Wahid, F.; Alamri, S.; Khan, F.; Dawar, K.M.; Irshad, I.; et al. Phosphorus Nutrient Management through Synchronization of Application Methods and Rates in Wheat and Maize Crops. Plants 2020, 9, 1389. [CrossRef] 
22. Wahid, F.; Fahad, S.; Danish, S.; Adnan, M.; Yue, Z.; Saud, S.; Siddiqui, M.H.; Brtnicky, M.; Hammerschmiedt, T.; Datta, R. Sustainable management with mycorrhizae and phosphate solubilizing bacteria for enhanced phosphorus uptake in calcareous soils. Agriculture 2020, 10, 334. [CrossRef]

23. Danish, S.; Younis, U.; Akhtar, N.; Ameer, A.; Ijaz, M.; Nasreen, S.; Huma, F.; Sharif, S.; Ehsanullah, M. Phosphorus solubilizing bacteria and rice straw biochar consequence on maize pigments synthesis. Int. J. Biosci. 2015, 5, 31-39.

24. Ahmed, N.; Ahsen, S.; Ali, M.A.; Hussain, M.B.; Hussain, S.B.; Rasheed, M.K.; Butt, B.; Irshad, I.; Danish, S. Rhizobacteria and silicon synergy modulates the growth, nutrition and yield of mungbean under saline soil. Pak. J. Bot. 2020, 52, 9-15. [CrossRef]

25. Zafar-ul-Hye, M.; Danish, S.; Abbas, M.; Ahmad, M.; Munir, T.M. ACC deaminase producing PGPR Bacillus amyloliquefaciens and Agrobacterium fabrum along with biochar improve wheat productivity under drought stress. Agronomy 2019, 9, 343. [CrossRef]

26. Zafar-ul-Hye, M.; Zahra, M.B.; Danish, S.; Abbas, M.; Rehim, A.; Akbar, M.N.; Iftikhar, A.; Gul, M.; Nazir, I.; Abid, M.; et al. Multi-strain inoculation with pgpr producing acc deaminase is more effective than single-strain inoculation to improve wheat (Triticum aestivum) growth and yield. Phyton 2020, 89, 405-413. [CrossRef]

27. Mandal, S.; Dutta, P.; Umdar, S.M.A.J. Plant growth promoting and antagonistic activity of bacillus strains isolated from rice rhizosphere. Int. J. Pharma Bio. Sci. 2017, 8, 408-415. [CrossRef]

28. Tara, N.; Ali, M.A.; Ahmad, N.; Danish, S.; Hassan, W.; Saba, T.; Hussain, M.B. Evaluation of Phosphate Solubilizing Bacteria Role with Biochar on the Growth of Wheat. Int. J. Biosci. 2019, 14, 349-356.

29. Sharma, S.; Kumar, V.; Tripathi, R.B. Isolation of Phosphate Solubilizing Microorganism (PSMs) from Soil. J. Microbiol. Biotechnol. Res. Sch. Res. Libr. J. Microbiol. Biotech. Res. 2011, 1, 90-95.

30. Ahmad, F.; Ahmad, I.; Khan, M.S. Screening of free-living rhizospheric bacteria for their multiple plant growth promoting activities. Microbiol. Res. 2008, 163, 173-181. [CrossRef]

31. Gholami, A.; Shahsavani, S.; Nezarat, S. The Effect of Plant Growth Promoting Rhizobacteria (PGPR) on Germination, Seedling Growth and Yield of Maize. Int. J. Biol. Life Sci. 2009, 5, 19-24.

32. Nadeem, S.M.; Zahir, Z.A.; Naveed, M.; Arshad, M. Rhizobacteria containing ACC-deaminase confer salt tolerance in maize grown on salt-affected fields. Can. J. Microbiol. 2009, 55, 1302-1309. [CrossRef]

33. Wu, Q.S.; Srivastava, A.K.; Zou, Y.N. AMF-induced tolerance to drought stress in citrus: A review. Sci. Hortic. (Amst.) 2013, 164, 77-87. [CrossRef]

34. Xu, H.; Lu, Y.; Tong, S. Effects of arbuscular mycorrhizal fungi on photosynthesis and chlorophyll fluorescence of maize seedlings under salt stress. Emir. J. Food Agric. 2018, 30, 199-204.

35. Mondal, M.; Skalicky, M.; Garai, S.; Hossain, A. Supplementing nitrogen in combination with rhizobium inoculation and soil mulch in Peanut (Arachis hypogaea L.) production system: Part II. Effect on phenology, growth, yield attributes, pod quality, profitability and nitrogen use efficiency. Agron. J. 2020, 10, 513. [CrossRef]

36. Whitaker, J.R.; Ritchie, G.L.; Bednarz, C.W.; Mills, C.I. Cotton subsurface drip and overhead irrigation efficiency, maturity, yield, and quality. Agron. J. 2008, 100, 1763-1768. [CrossRef]

37. Gerik, T.J.; Faver, K.L.; Thaxton, P.M.; El-Zik, K.M. Late Season Water Stress in Cotton: I. Plant Growth, Water Use, and Yield. Crop Sci. 1996, 36, 914-921. [CrossRef]

38. Tank, N.; Saraf, M. Phosphate solubilization, exopolysaccharide production and indole acetic acid secretion by rhizobacteria isolated from Trigonella foenum-graecum. Indian J. Microbiol. 2003, 43, 37-40.

39. Zahid, M.; Abbasi, M.K.; Hameed, S.; Rahim, N. Isolation and identification of indigenous plant growth promoting rhizobacteria from Himalayan region of Kashmir and their effect on improving growth and nutrient contents of maize (Zea mays L.). Front. Microbiol. 2015, 6, 207. [CrossRef]

40. Majeed, A.; Abbasi, M.K.; Hameed, S.; Imran, A.; Rahim, N. Isolation and characterization of plant growth-promoting rhizobacteria from wheat rhizosphere and their effect on plant growth promotion. Front. Microbiol. 2015, 6, 198. [CrossRef]

41. Watson, D.J. The Physiological Basis of Variation in Yield. Adv. Agron. 1952, 4, 101-145.

42. R_Core_Team. R: A Language and Environment for Statistical Computing; R Foundation for Statistical Computing: Vienna, Austria, 2020.

43. Lenth, R. V Least-Squares Means: The R Package Lsmeans. J. Stat. Softw. 2016, 69. [CrossRef] 
44. Gwathmey, C.O.; Leib, B.G.; Main, C.L. Lint yield and crop maturity responses to irrigation in a short-season environment. J. Cotton Sci. 2011, 15, 1-10.

45. Pettigrew, W.T.; Meredith, W.R. Molecular biology and physiology genotypic variation in physiological strategies for attaining cotton lint yield production. J. Cotton Sci. 2012, 16, 179-189.

46. Jaleel, C.A.; Llorente, B.E. Drought stress in plants: A review on water relations. Biosci. Res. 2009, 6, $20-27$.

47. Lawlor, D.W.; Cornic, G. Photosynthetic carbon assimilation and associated metabolism in relation to water deficits in higher plants. Plant Cell Environ. 2002, 25, 275-294. [CrossRef] [PubMed]

48. Chutipaijit, S.; Cha-Um, S.; Sompornpailin, K. An evaluation of water deficit tolerance screening in pigmented indica rice genotypes. Pak. J. Bot. 2012, 44,65-72.

49. Gulnaz, Y.; Fathima, P.S.; Denesh, G.R.; Kulmitra, A.K.; Shivrajkumar, H.S. Effect of plant growth promoting rhizobacteria (PGPR) and PSB on root parameters, nutrient uptake and nutrient use efficiency of irrigated maize under varying levels of phosphorus. J. Entomol. Zool. Stud. 2017, 5, 166-169.

50. Shao, Y.; Zhang, D.; Hu, X.; Wu, Q.; Jiang, C.; Xia, T.; Gao, X.; Kuča, K. Mycorrhiza-induced changes in root growth and nutrient absorption of tea plants. Plant Soil Environ. 2018, 64, 283-289.

51. Gomare, K.S.G.K.S.; Biotechnology, C.D.O.; Mese, M.M.M.; Shetkar, Y.S.Y. Isolation of Azotobacter and Cost Effective Production of Biofertilizer. Indian J. Appl. Res. 2011, 3, 54-56. [CrossRef]

Publisher's Note: MDPI stays neutral with regard to jurisdictional claims in published maps and institutional affiliations.

(C) 2020 by the authors. Licensee MDPI, Basel, Switzerland. This article is an open access article distributed under the terms and conditions of the Creative Commons Attribution (CC BY) license (http://creativecommons.org/licenses/by/4.0/). 